原著

\title{
T型シートを用いた内視鏡下涙囊鼻腔吻合術
}

\author{
西池 季隆1), 今井 貴夫年, 大島 一男1), \\ 田中 秀憲 ${ }^{1)}$, 鶴田 幸之 ${ }^{1)}$, 富山要一郎 ${ }^{1)}$ \\ ${ }^{1)}$ 大阪労災病院耳鼻咽诶科·頭頸部外科 \\ ${ }^{2}$ 大阪大学大学院医学系研究科耳鼻咽喉科・頭頸部外科学
}

\begin{abstract}
沪囊鼻腔吻合術（DCR）では, 術後に淚管チューブを上下涙点から挿入し, 沪囊開空部を通して鼻内に留置 することが多い。我々は以前から内視鏡下に涙囊を鼻胅から開空したのちに同部にT型シートを留置している。 この方法では, 涙点の操作は必要ないため, 耳鼻咽喉科単独で容易にDCRが行える利点がある。手技として, 鼻腔側壁粘膜に切開を加え粘膜弁を剥離し，ドリルにて上顎骨前頭突起㧍よび涙骨を削開し，沪囊から鼻涙管 にかけて露出したのち, 垂直に切開を加え観音開きにし, 涙䧶開空部にT字型に作成したペンローズドレーン を留置する。最後に形成した粘膜弁にて覆う。シートは 2 週間から 1 力月で抜去している。経過を追えた 17 例 20側に対して検討を行った。術後の再発例は 2 側であり, 成功率は $90 \%$ であった。DCRにおけるT型シート留 置術は，耳鼻咽喉科医にとって手技として容易であり，勧められる方法である。
\end{abstract}

キーワード：内視鏡, 涙㶞鼻腔吻合術, T型シート

\section{T-sheet Stent after Endoscopic Dacryocystorhinostomy}

\author{
Suetaka Nishiike $^{1)}$, Takao Imai ${ }^{2)}$, Kazuo Oshima ${ }^{1)}$, \\ Hidenori Tanaka $^{1)}$, Yukinori Tsuruta ${ }^{1)}$, Yoichiro Tomiyama ${ }^{1)}$ \\ ${ }^{1)}$ Department of Otorhinolaryngology - Head and Neck Surgery, Osaka Rosai Hospital \\ ${ }^{21}$ Department of Otorhinolaryngology - Head and Neck Surgery, Osaka University Graduate School of Medicine
}

After dacryocystorhinostomy (DCR), a silicon tube is generally inserted into the superior and inferior puncta and then passed through the canaliculi to the opened lacrimal sac. Instead, we insert a T-sheet into the opened sac after DCR. In this method, an incision is made on the ridge of the nose, and a flap is elevated. A DCR diamond burr is used to remove the bone and expose the lacrimal sac and the nasolacrimal duct surface. Then, a vertical incision is made in this region. Next, a T-sheet is made from a Penrose drain tube. The horizontal part of the T-sheet is inserted into the sac and is left in the sac for 2 to 4 weeks. Twenty sacs in 17 cases have been subjected to the above method in the past 14 years. Two cases required further surgical procedures, and the success rate was $90 \%$. Physicians who are familiar with endoscopic sinus surgery can easily perform the reported procedure.

Key words : endoscope, dacryocystorhinostomy, T-sheet

(2015年12月17日受稿, 2016年6月21日受理) 
はじめに

涙囊鼻腔吻合術（dacryocystorhinostomy: DCR）は, 鼻涙管閉塞症に対して広く行われている術式である。以 前は，顔面皮切を伴う鼻外法により行われていたが，最 近では低侵襲な鼻内法により行われることが多くなって いる ${ }^{1.22}$ 。通常，DCRを行った術後には，涙管チューブを 上下涙点から総涙小管を通り, 開放された涙囊から鼻腔 にかけて留置することが多い1,22。

それに対して, 我々は以前から涙襄開空部にT型シー 卜を留置している3)。T型シートは開放された涙囊腔に 鼻腔側から押し込んで留置する。この方法では，上下涙 点および総涙小管の操作の必要性がないため, 耳鼻咽喉 科医単独でも行いやすい手術である。览玉らが芷，シート や皮弁の形状に工夫を行いその変法を報告した。

T型シートを用いた内視鏡下DCRは耳鼻咽喉科医に とって利点の多い方法と考え紹介する。

\section{方法}

T型シートを用いたDCRの手順は，まず鼻内切開およ び粘膜弁を作成する。そのために，右鼻腔に対しては逆 コの字切開, 左鼻胿に対してはコの字切開を加えるよう にしている（図1A）。ついで粘膜弁を翻転し，上顎骨前
頭突起および涙骨の削開を，DCRバー，スタンツェおよ び鋭匙を使用して行う（図1B）。一般的なDCRでは涙囊 の露出に留まるが，当科では鼻涙管および涙囊をできる だけ広範に露出する。その際，ブジーやライトガイドは 必須でない。涙囊の切開は，まず縦に大きく涙囊から鼻 涙管にかけて切開し，その後T字あるいは工字に切開を 延長して観音開きとする（図1C）。

T型シートは, $10 \mathrm{~mm}$ 幅のペンローズドレーンから作成 している（図1D）。T字の水平部分に, ペンローズのX線 不透過ラインが含まれるように形成している。T字の水 平および垂直部分の長さは1.0 1.5 cmとしている。 $\mathrm{T}$ 字 の水平部分は通常は $1.5 \mathrm{~cm}$ ぼの大きさとしているが, 涙囊壁の肥厚した症例や涙囊の小さな症例ではこの大き さを約 $1.0 \mathrm{~cm}$ とている。

T型シートのTの水平部分を開放した涙囊に挿入する (図1E)。形成した粘膜弁による被覆を行う（図1F）。

T型シート導入期には，シートを数ヶ月ほど留置する 症例があったが，涙囊鼻腔吻合部の上皮化は早期に完成 されると考えられるため, 最近では 2 週間から 1 ケ月ほ どで抜去している。

2000年 5 月から 2014 年 4 月にかけて, 大阪大学医学部 附属病院および大阪労災病院にてT型シートを用いた DCRを行った17症例に関して検討を行った。

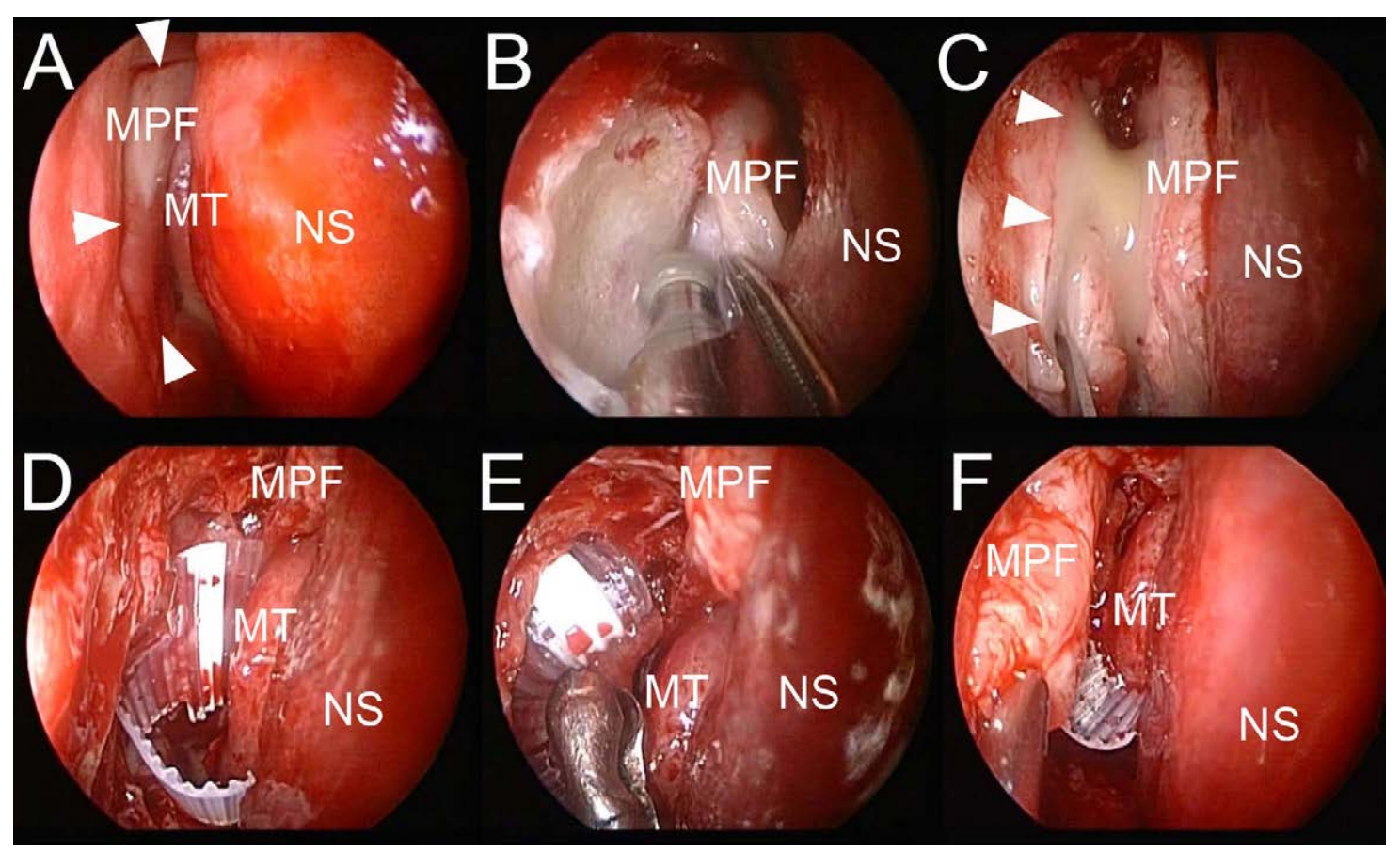

図 $1 \mathrm{~T}$ 型シートを用いた内視鏡下涙囊鼻腔吻合術。右鼻腔に対する手術。 $\mathrm{A}$ ：逆コの字切開（矢頭）を右鼻腔に加えMPFを形成 した。B：DCRダイヤモンドバーにて涙骨の削除を行った。C：露出した涙囊を縦に切開した（矢頭）。大量の膿が排出さ れた。 D : ペンローズドレーンを形成したT型シート。 $\mathrm{E} ： \mathrm{~T}$ 字の水平に当たる部分を鉗子にて涙囊に押し込んだ。 $\mathrm{F} ：$ 粘骨 膜弁を戻し，骨露出部を覆った。NS：鼻中隔，MPF：粘骨膜弁，MT：中鼻甲介。 


\section{結 果}

対象は鼻涙管閉塞症17例で，18件の手術を20側に行っ た。男性 4 名, 女性13名であった。平均年齢は66歳（31 歳から88歳) であった。右側の手術を 9 例に, 左側の手 術を 7 例に, 両側手術を 2 例に行った。20側の内訳は, 初回手術は 18 側, 再手術は 2 側であった。再手術 2 側の 内訳は，初回涙管チューブに対する失敗例に対するT型 シート挿入術を行った右鼻涙管閉塞症の 1 側と初回 $\mathrm{T}$ 型 シートで再手術もT型シート挿入術を行った右涙囊炎の 1 側である。後者の例で, 1 症例に対して 2 件のT型シー 卜挿入術が計上されている。これらの再手術例では，初 回手術の際に作成した涙囊鼻腔吻合部が閉塞したことが 失敗の原因と考えられ，再手術では大きな沪襄鼻腔吻合 部を作成し，T型シートを挿入することで対応した。

全例で, 涙点の違和感や断裂等の涙管チューブに伴う ような合併症は認めなかった。術後にT型シート挿入部 に肉芽が形成されることがまれにあるが，シート抜去後 にはそれらは消失した。涙囊鼻腔吻合部の術後創として, 涙管チューブ抻入後と比較しても，大差はなかった。ま たT型シートが涙襄吻合部から逸脱して紛失した症例も なかった。

平均フォローアップ期間は36ケ月（6ケ月から122ケ 月）である。T型シート挿入術の術後評価として, 症状 の自覚的改善と認めた場合を成功例とし, 症状の改善が ない症例あるいは症状の再発を認めたものを失敗例とす ると, 成功症例は 20 側中の 18 側であり, 成功率は $90 \%$ で あった。失敗例の 2 側は, 症状の再発を認めたために再 度DCRを行った。その内訳は, 再度T型シート挿入術を 行った上述の右涙囊炎の 1 側と再手術で涙管チューブ を使用した右涙囊炎の 1 側である。いずれの症例も涙囊 鼻腔吻合部の狭窄が再発の原因であり, 大きな吻合部を 作成することで対応した。また後者の再手術例での涙管 チューブ挿入例は, T型シート導入初期のために再手術 例では涙管チューブを挿入しているが, 現在ではT型 シートを選択すると考えられる。2例いずれも再手術後 に症状は改善した。手技として安定してきた2003年以降 の10例10側では再発は認めていない。

実際の症例を提示する。

症例は88歳女性, 主訴は右流涙, 右眼脂, 既往歴とし て，9年前に両高度難聴に対して右人工内耳を施行され ている。現病歴では, 右鼻涙管閉塞症にともなう上記症 状に対して，2 年前に他の術者にて涙管チューブを使用 した右DCRを施行された。しかし早期に涙管チューブが 抜けて，その後眼脂が多くなっていた。今回DCRの再手
術を希望された。

手術は局所麻酔下に行った。右鼻腔側壁に逆コの字型 に切開を加え，DCRバーにて鼻涙管から涙囊にかけて大 きく露出するように骨削開を行った（図 1 )。涙囊から 鼻涙管に切開を行い，涙囊を観音開きにした。この症例 では, T型シートは水平 $1.2 \mathrm{~cm}$, 垂直 $1.5 \mathrm{~cm}$ の長さとした (図1D)。T型シートを涙囊に挿入し, 粘膜弁を戻した。 手術時間は53分で，出血は少量であった。

当症例では, T型シートを 2 週間ほど留置した。術後 半年の状態で, 流涙の症状は消失し, 涙囊からの涙の流 出も良好であった。

\section{考察}

DCRで，術後に涙管チューブを上下涙点から㨂入し， 涙囊開密部を通して鼻内に留置する方法は広く行われて いる ${ }^{1,2)}$ 。涙管チューブ留置の利点としては, 涙点狭窄, 涙小管狭窄に有効であるとされている1”。の欠点として は，涙管チューブの本来ない誤った仮道への留置の可能 性がある2)。また，涙管チューブの刺激による涙点の鼻 側への断裂の可能性がある ${ }^{5}$ 。涙管チューブの抜去に関 しては，涙点側から抜去することもできるが，中鼻道に 留置された涙管チューブからの菌検出率は早期から高率 であり，そのためチューブ抜去は鼻腔側から行う方がよ いとの報告がある6 。

Tamura et $\mathrm{al}^{3}{ }^{3}$ は, 涙囊開密部にT型シートを留置する 方法を開発した。児玉らが苟，最近その変法を報告した。 T型シートを用いたDCRの適応症としては, 鼻涙管閉塞 症が挙げられる。しかし，この方法では術中操作として 涙点や涙小管を操作しないため, 適応外として涙点や涙 小管の疾患が挙げられる。T型シートは鼻内から挿入し 鼻内から抜去するため，涙管チューブのように抜去方向 に関して検討する必要はない。

T型シートを用いたDCRの利点としては, 涙点㧍よび 総涙小管の操作を必要とせず，耳鼻咽喉科単独で容易に 行える点が挙げられる。術後の患者フォローでステント による異物感の訴えがないことも利点である。また，涙 管チューブを留置した際に起こりえる涙点の鼻側への断 裂は起こらない。一方，その欠点としては，上述したよ うに涙点や涙小管の疾患に刘応出来ないことである。

また筆者は経験ないが, 術後にT型シートが涙囊鼻腔 吻合部から逸脱し，紛失する危険性は否定できない。こ れに関しては，X線不透過ラインを含んだシートを作成 することにより，紛失の際にレントゲン撮影を行うこと によって，身体内の紛失物を発見することができると考 える。沪管チューブに関しては，それが紛失する可能性 
表 1 涙管チューブとT型シートの比較

\begin{tabular}{ccc}
\hline & 涙管チューブ & T型シート \\
\hline 適応 : 涙囊・鼾涙管疾患 & 適応あり & 適応あり \\
涙点・総涙管疾患 & 適応あり & 適応なし \\
術中 : 眼科医の協力 & 必要あり & 必要なし \\
術後 : 涙点の違和感 & あり & なし \\
涙点断裂の可能性 & あり & なし \\
異物として紛失の可能性 & なし & あり \\
ステント抜去方向 & 涙点側あるいは鼻腔側 & 鼻腔側 \\
\hline
\end{tabular}

はT型シートに比較して少ないと考えられる。表 1 に上 述した涙管チューブとT型シートの比較をまとめた。

Tamura et $\mathrm{al}^{3)}$ は，T型シートを用いたDCRを開発し 導入した理由は, 現場での必要に駆られた選択であった とかつて筆者に語った。診療現場において, DCR時に眼 科医が手術に参加する場合には，沪管チューブあるいは T型シートいずれも術後のステントとして選択可能で あるが，眼科医がステント採用に関して主導権を握って いることから，涙管チューブが留置されるであろう。一 方で, 耳鼻咽喉科医にDCRの依頼があるものの, 手術に 眼科医の助力がない場合がある。この際, 耳鼻咽喉科医 にとっては小涙点のプローヴィングや涙管チューブ挿入 は容易ではなく，その必要性のないT型シート留置の利 点が大きい。Tamara et $\mathrm{al}^{3)}$ は実際にそのような状況に 遭遇したため，T型シートを用いたDCRを開発したとの ことであった。

DCR後のステント留置の必要性に関しては, 術後に ルーチーンに留置している施設が多いと考えられる が2.5), Smirnov et alは ${ }^{7)}$, 初回手術で定期的受診可能な 患者であればステントは必要ないと報告している。一方 で, Callejas et alは8 ${ }^{8}$, 総涙小管の問題がある症例によっ ては初回手術でも必要であるとしている。当科では, 遠 方から来院したり, 当科での診療待ち時間が長時間に及 んだりする問題から, 頻繁な通院が困難なケースが多い。 また, T型シートの挿入は容易である。このことから, ス テント留置に関する当科の方針としては, DCR後には ルーチーンにT型シートを鼻内に留置している。しかし, 当科でこの術式を行っている対象疾患は鼻涙管閉塞症で あり, Callejas et $\mathrm{al}^{8)}$ がステントの必要性を指摘している 上下涙点および総涙小管の疾患ではない。

\section{まとめ}

1. T型シートを用いたDCRは, 涙点および総涙小管の操 作を必要としないため, 耳鼻咽喉科単独で行える手術 法である。

2. 適応疾患は鼻涙管閉塞症である。

3. 涙点の操作を行わないことから, 涙点の鼻側への断裂 等の涙点周辺の合併症は起こらない。

4. T型シート留置術は手技として容易であり, 耳鼻咽喉 科医に勧められる方法である。

なお本論文の要旨は, 第54回日本鼻科学会総会（広島） にて公募指定演題として発表した。

\section{参考文献}

1 ）森寺威之, 高木史子, 寺井実知子, 他：涙道閉塞の 治療におけるヌンチャク型シリコーンチューブと涙 囊鼻腔吻合術の適応. 眼科手術 $1999 ; 12: 249-252$.

2）廣瀬浩士：いかに治療すべきか 涙道疾患の手術的 治療. 現代医学 $2004 ; 51 ： 491-498$.

3 ) Tamura M, Kawasaki Y, Mori K, et al : Endoscopic dacryocystorhinostomy using T-sheet. Laryngoscope $2003 ; 113: 746-748$.

4 ）肾玉 悟, 平野 隆, 鈴木正志 : 内視鏡下涙囊鼻腔 吻合術 粘膜弁に工夫したWormald変法. 日本耳鼻 咽喉科学会会報 $2011 ; 114: 820-823$.

5 ) 広瀬浩士 : 流涙 ヌンチャク型シリコンチューブに よる涙道閉塞治療. 眼科臨床医報 $1999 ; 93$ : 15571562.

6 ）大野木淳二：涙囊鼻腔吻合術鼻外法における涙管 チューブ抜去後の菌検査. 臨床眼科 $2013 ； 67: 745$ 748.

7 ) Smirnov G, Tuomilehto H, Terasvirta M, et al : Silicone tubing after endoscopic dacryocystorhinostomy: Is it necessary? Am J Rhinol 2006 ; 20 : 600-602.

8 ) Callejas CA, Tewfik MA, Wormald PJ : Powered endoscopic dacryocystorhinostomy with selective stenting. Laryngoscope $2010 ; 120$ : 1449-1452. 